\title{
Michel Henry: Sense of self and hallucination
}

\author{
Michel Henry: sentimento de si e alucinação
}

Florinda MARTINS ${ }^{1}$

Andrés Eduardo Aguirre ANTÚNEZ²

\begin{abstract}
In this paper we develop the thesis of the possibility of understanding human beings, starting from the phenomenality of their therapeutic needs. We bring the phenomenality of hallucination to the center of the debate. We show how, in Michel Henry, the phenomenality of sight, touch and anguish is, in all, comparable to the phenomenality of hallucination. From the starting point of this phenomenality we will understand human actions and thus, the essence of clinical practice.
\end{abstract}

Keywords: Affect; Feeling; Hallucination; Michel Henry; Therapy.

\section{Resumo}

Neste texto desenvolveu-se a tese da possibilidade da compreensão do humano a partir da fenomenalidade das suas necessidades terapêuticas. A fenomenalidade da alucinação é trazida para o centro do debate. Buscou-se mostrar como é que, em Michel Henry, a fenomenalidade da visão, do tato e da angústia é em tudo comparável com a fenomenalidade da alucinação. Será a partir dessa fenomenalidade que se compreenderá o agir humano e, com ela, a essência da clínica.

Palavras-chave: Afeto; Sentimento; Alucinação; Michel Henry; Terapia.

The work of Michel Henry "Genealogy of Psychoanalysis" (Henry, 1985) recaptures a thesis of Descartes so that we can, even today, extract contributions to the intelligibility of emerging issues in our culture, which involve rethinking a tradition in its various aspects: philosophy, science, politics, ethics, aesthetics, and even religion. We refer to the thesis according to which the truth of phenomena arises from their effective origination, and is experienced in and through the phenomenality of feeling. A thesis whose reception in health sciences - clinical practice and psychiatry, psychology, psychoanalysis, therapeutic monitoring, free-expression painting studio -, opened space for interdisciplinary research of which this text is part (Antúnez, Martins, \& Ferreira, 2014, 2015).This

\footnotetext{
1 Universidade Católica Portuguesa, Faculdade de Ciências Humanas, Centro de Estudos de Filosofia. Porto, Portugal.

2 Universidade de São Paulo, Instituto de Psicologia, Departamento de Psicologia Clínica. Av. Prof. Mello Moraes, 1721, 05508-030, Cidade Universitária, São Paulo, SP, Brasil. Correspondência para/Correspondence to: A.E.A. ANTÚNEZ. E-mail: <antunez@usp.br>. Support: Fundação de Amparo à Pesquisa do Estado de São Paulo (Process no 13/24735).
} 
space is made possible by the phenomenality of feeling that refers us to a transcendental experience that allows us to understand the dynamics of the human being in a context of previous phenomenality and much broader than the one related to the search of subject/object suitability.

Now, from the phenomenality of this originating process of our life, the following passage of Descartes, taken from the "Genealogy of Psychoanalysis", includes the theme of sense of self and hallucination:

We may be deceived by perceptions that refer to objects that are external to us, and by perceptions that refer to our body, but we cannot be deceived in the same way by our passions because they are so close and so interior to our soul that it is impossible to feel them differently. Thus, often while sleeping and even sometimes when awake, one imagines certain things so strongly that he thinks he can see them before himself or feel them in his body, even if they are not there. But even if he is asleep or dreaming, it would not be possible for him to feel sad or moved by any other passion without it being true that the soul has that passion within itself (Henry, 1985, p.37).

It is a perplexing text once you realize Descartes trusts the experience of the truth of things. He trusts, but he gives himself an ambit of phenomenality, the retrieval of which involves much more than the reversal of the processes and methodologies of traditional phenomenology that came from this ambit but had been forgotten. It involves the immersion in the phenomenality of which, in traditional phenomenology, is shown to reason as something unknown to it, irrational, and savage, to understand it, at the heart of its effectiveness, its origin or raison d'être. What is being considered here is, first of all, the attention to the rationality inherent to the phenomenality of what is comprehensible only by feeling. Therefore, what was an irrational assumption appears with inherent rationality that is seen in the ambit of the pure affection of life, which is given to us through is irreducible to that anonymous thing which I confront and turns out to be that which arises in me for me to feel. That prevents me from hypostatizing the feeling because I am what I feel. That is what this enigmatic and, therefore, notinfrequently quoted expression of Michel Henry means (Henry, 2001; Marques, 2002): "feeling never is and never will be able to be sensed... feeling cannot be perceived either" (Henry, 1963, p.579).

So what I am, what constitutes me, that which is within the limit of intentionality is given to me through the experience of feeling of an affection of life: in Michel Henry, community is suddenly what I am. Michel Henry says: "naturally the essence of community is nothing more than that - not this -, that arises as a tireless onslaught of life, and thus of oneself" (Henry, 1990, p.178).

I am what I feel, but what I feel is an affection of life, in which and through which someone experiences himself. The ambit of the affection of life reveals this affection in its singularity, in the fabric of affections: affection of life. This affection can be of my life in relation to the life of everyone and of each one of us; of our lives in relation to everything that happens, within it, as affection. Now, this affective dimension of life occupies other fields of research today, not only in the area of philosophy phenomenology, analytic philosophy, philosophy of mind, sciences of cognition -, but also in sciences, especially in neurosciences. Therefore, what was ironically presented in Michel Henry as the "truth that only a madman can say" (Henry, 1981, p.51) is today an object of investigation in all the areas of knowledge and culture. An irreducible truth to the truth of a madman, even though, as we shall see, this truth may contribute to the understanding of the truth spoken by a madman.

The connection between the truth of a madman and the truth of ourselves or even the connection between the truth of phenomenology and the truth of neurosciences, particularly in the psychiatric and psychoanalytical dimension, is pointed out by Michel Henry in his work "The Son of the King". 
Along this path, we will consider hallucination as a paradigm of the phenomenality of the affective life. First we will show how Michel Henry brings the phenomenality of life closer to the phenomenality of hallucination, in order to then show the receptivity of this theory in health sciences.

\section{Limiting the truth of ourselves to the truth of feeling}

To limit the truth of ourselves to the truth of feeling implies addressing an ambit of phenomenality that takes place in an earlier record and is indifferent to whether or not it is possible to distinguish subjectivity/objectivity. It is an ambit in which the primordial experience of ourselves is the experience of pure affection of life in the sense modalities of hearing, sight, anxiety, fear. Through these modalities, life installs itself in us as what we are, thus causing itself to be experienced. However, if the phenomenality of what we are, just as hallucination, is experienced as a feeling of affection of life; in this experience, the intensity with which we feel these affections changes. The intensity can range between unbearability and anesthesia, and if unbearability can lead to madness, anesthesia or silence of the senses can lead to alienation from oneself. This is how hallucination overcomes alienation: the unbearability of hallucination prevents us from ignoring the truth of ourselves; it prevents us from forgetting the possibilities and the limits of our actions, in their many modalities. The truth for actions is part of the truth of life.

However, even though the connection between feeling and acting is extremely important to the phenomenality of hallucination, we will explore this connection in section 4, but for now we shall discuss how hallucination is a paradigm of the originating phenomenality of life in Michel Henry.

And if there are doubts regarding the fairness of this thesis in the philosophical work "The Genealogy of Psychoanalysis", they diminish in "The Son of the King" and they disappear entirely in later works. In these works we find some elements that unequivocally support that by showing the truth of ourselves, not being limited to the truth of objects, we are allowed to understand the phenomenality of hallucination in light of the phenomenology of life, and thus rethink a tradition whose paradigm of rationality set aside or abandoned essential questions.

Using phenomenological analysis in terms of sight, touch, and anguish, Michel Henry eliminates any doubt about the possibility of the interpretation we address regarding his phenomenology. Let us look at the evidence.

\section{The importance of sight and touch for understanding the truth that can be experienced through feeling}

Although the phenomenality of feeling is, according to Michel Henry, irreducible to the phenomenality of the traditional senses - sight, hearing, touch, smell... -, once anguish, apprehension, despair, fear, pain, suffering, joy and hallucination can also be felt, we will show how, in the phenomenality of sight and touch, he connects senses and hallucination. For this connection we have chosen one of the dialogues that Michel Henry weaves with Descartes, and an exceptional reference to Aristotle (Henry, 2000), because they suffice for us to be able to see that what is at issue are the real possibilities of a phenomenality - the phenomenality of the senses -, particularly regarding the understanding of what constitutes us and cannot be left to the domain of the irrational or mental illness. Only by connecting feeling and movement will it be possible to successfully complete the task of removing from mere speculation the issues that philosophy poses (Husserl), understanding that being and life, without taking into consideration their separation into subjectivity and objectivity (Heidegger).

However, the phenomenality of the experience of the senses demands more than the reversal of the path of phenomenology that oscillates between noema and noesis; creature and being, body and flesh, visible and invisible, to situate ourselves in terms of their phenomenality because they are the ones that endure this path and they 
are the condition for following the path. According to Descartes, it is within the limits of feeling that we know ourselves in the sense modalities: a being who doubts, loves, hates, wants, rejects, walks, sees, imagines, dreams, feels; a being who knows himself doubting, loving, hating, wanting, imagining, feeling. That is, a being who "is only what he thinks" or who "is only what he feels". A being who is in the sense of self in which thinking and acting are experienced while feeling them. Neither is the judgment external to the agent, nor is the agent external to the product of his actions: one cannot be without the other. And because they are accomplished in the affect, the affection is the reality of one's life and one's future.

It is interesting then to understand a life that establishes its possibilities from within its limits because once we are within our limits of feeling that is what is really irreducible. It is that which by itself imposes itself as completely true. In phenomenological terms it is that which phenomenological reduction cannot reduce and whose domain is part of what Michel Henry calls counter-reduction - Cartesian counter-reduction (Henry, 2000).

In this domain and in relation to the phenomenality of seeing, Michel Henry collects, in order to analyze in phenomenological terms, expressions such as "see oneself seeing and feeling oneself seeing". From these analyses we highlight the idea of understanding the phenomenality of seeing as "feeling oneself see" - feeling ourselves seeing -, that is, phenomenologically limited to the "sense of self, the idea of externality is a derived idea" (Henry, 1985, p.38).

This is not an isolated idea in the phenomenology of life. It is recaptured by the analyses of touch to show that everything that is real is processed in the domain of affectivity that is itself felt: it feels in the absence of touching (Henry, 2000).

Will there be anything closer to hallucination than the phenomenology of life in Michel Henry? There is nothing closer! We could even say there is nothing more identical. However, it is this property
Aristotelian question of movement and action (Henry, 2000) to an ambit of phenomenality that will answer the questions that we pose today: the questions concerning a body that, feeling the affections of life, moves and is realized in life. To summarize, a body that lives in and of life. We see the same thing in Michael Henry when he says that the phenomenality of touch changes not only our comprehension of reality but also reality itself: "then reality has changed" (Henry, 2000, p.211).

These analyses of the phenomenality of the senses of sight and touch as phenomenological analyses of feeling are extensible to the phenomenality of pain, anguish, fear, despair and hallucination, that is, to the experiential unity of our living. Therefore, the possibility of our actions can be inferred from these words of Michel Henry: "man begins where this life starts, defined as how to feel himself, how to experience, and he ends where it ends. This domain of phenomenality is the domain of ethics" (Henry, 2010, p.10).

It is in this connection between sense of self and ethics that it is possible to answer, starting from the Cartesian corpus, from the evidence of truth in the phenomenality of feeling, the questions resulting from the link between ethics and the affections of the life of the body. To show this possibility let us first see how the phenomenality of anguish operates towards the final judgment of the body and, with it, towards the final judgment of a tradition.

\section{Towards the final judgment of the body, towards the final judgment of a tradition: The phenomenality of anguish on the path opened by phenomenological reduction}

The examples of phenomenality of sight and touch show that, methodologically, the phenomenological reduction more than limits a certain field of research, opens a transcendental experience irreducible to any methodological procedure: it opens to the originating experience 
of seeing and touching. Michel Henry describes this experience as a "transcendental experience of an indefinitely evocable power" (Henry, 1985, p.395) and, as such, a source of pleasure: the eye that sees wants to see even more...! But what is the experience of this indefinitely evocable power if not the experience of freedom within the phenomenality of feeling: of pathos? The phenomenality of anguish answers this question: "the anguish suffers from the law of pathos and the dizziness of freedom at the same time" (Henry, 1985, p.276).

The fertility of the field of research opened by this ambit of phenomenality that connects the law of pathos and freedom, in Michel Henry, leads to several directions, of which aesthetics, politics and religion are the best known. However, it is in this connection between sense of self and hallucination that these directions, among others, accomplish the goal intended by Michel Henry: to find in the relationship between freedom and pathos a way out of the prison of being and of life in themselves. However, if Michel Henry establishes this relationship between pathos and liberty through the phenomenality of anguish, it is through the phenomenality of hallucination that the possibility of escaping this prison paradoxically becomes present. First because this way out is not only presented as a possible "task" from which one wants to escape (Henry, 1985), but it is also how I truly become myself! Second, because when all our tasks find the proper place of their realization, what is important is "not to succumb" (Henry, 1981, p.65) to any of the terms that make them possible: freedom and laws of pathos. In this relationship, the process of interior generation becomes effective, which matters today not only to phenomenology and theology, but also to politics, ethics, clinical practice, and aesthetics (Henry, 2004). But among us, the receptivity of material phenomenology has occurred mainly within the ambit of neurosciences, clinical practice, psychiatry, psychoanalysis and psychology, and it is within this context that we now connect sense of self and hallucination, showing the operation in clinical phenomenology of life presented here (Antúnez \& Martins, 2015).

\section{Revision of the state of the question we have developed in this article}

We have begun this article by questioning the possibility, through Descartes, to redefine the human being through the phenomenality of feeling. We contextualized the debate around this question, showing its importance at present, as both Henry and Marion (2003) present it as an answer to the epistemological contributions addressed mainly by the sciences of life. However, our first intention is to reach the irreducible specificity of the one who comes to the encounter of the therapist, hoping to understand oneself through his help. The phenomenality of feeling enables the understanding of the human being through the concreteness or positivity of his selfhood - his anguished, sad, absent being -, and not through a theoretical neurotic, psychotic model that redefines him by an ontological deficit.

Departing from the simple phenomenality of sight or touch we show how the human being inhabits them, because each and every dimension of feeling - seeing, listening, touching -, refers to the affective foundation of life that makes itself, within it, evident. That is, the phenomenality of feeling integrates and congregates the phenomenality of senses, being those much more than simple epiphenomena reducible to an empirical dimension or to a denounced exteriority. And even if it begins to be consensual along the new theories of cognition, the articulation between the sense evidences and the judgment inherent to its phenomenality, the issue of the redefinition of the human through this debate is not even, at times, considered.

Therefore, that is the central issue of this article through which we reflect upon the statement of Michel Henry that says that "when we understand the human being through the phenomenality of senses in itself, namely touching, then everything changes" (Henry, 2000, p.211). Everything changes: not only our understanding of the human changes, but its own reality. We remind, therefore, that the phenomenality of senses not only points to an effective donation of life, but yet to the pragmatic conditions of such donation. 
It is the phenomenality of anguish that opens us up to the investigation of such conditions. An anguished being is susceptible of being suspended of reality and circumstance, in a way to inhabit it with quality. Therefore, the phenomenality of feeling, instead of imprisoning us to reality, enables, through feeling itself, an opening and freedom to the other, to circumstance, time, and concrete conditions of our living that immediately interdicts any comprehension of the phenomenology of life. In Michel Henry, that is independent of such relationship inasmuch as the human being redefines himself in it and through it.

The operability of such phenomenality in psychotherapies is of utmost importance. Accordingly, section 4 assumes the phenomenality of anguish as indispensable to the understanding not only of the reality deficit, but the way of being of this being we call "human".

Issues such as the phenomenality of freedom through the phenomenality of feeling with the consequent relationship to its therapeutic possibilities are hereby approached in a way to present the operability of Michel Henry's phenomenology. In this regard, clinical practice once again challenges the phenomenologist, as it has been done in the introduction of this article. Issues, such as the possibility of redefining the roles and representations both of the therapist and the one who searches for him in order to understand himself, invite us to place the phenomenality of community, itself also, within the pragmatic boundaries of its outcome.

However, the phenomenality of community is not exclusively concerned with the relationship between therapist/ill patient. It also concerns the community of those who have the same purpose: "to return a sick life to its power and happiness of living" (Henry, 2001, p.142).

Faithful to such reflection of Michel Henry inasmuch as we believe it to be absolutely fair and present, we aspire for more than remembering it, we wish to give it continuity.

\section{Contributors}

All authors contributed to the concept and design of the study, data analysis and final editing.

\section{References}

Antúnez, A. E. A., \& Martins, F. (2015). Michel Henry: afetividade e alucinação. Revista da Abordagem Gestáltica, 21(2), 177-183.

Antúnez, A. E. A, Martins, F., \& Ferreira, M. V. (2014). Fenomenologia da vida de Michel Henry: interlocuções entre filosofia e psicologia. São Paulo: Escuta.

Antúnez, A. E. A., Martins, F., \& Ferreira, M. V. (2015). Apresentação: a fenomenologia da vida de Michel Henry e a psicologia clínica. Psicologia USP, 26(3), 316317. Recuperado em março 3, 2016, de http:// www.revistas.usp.br/psicousp/article/view/109962/ 108524

Henry, M. (1963). L'essence de la Manifestation. Paris: PUF.

Henry, M. (1981). Le fils du roi. Paris: Gallimard.

Henry, M. (1985). Généalogie de la Psychanalyse: Le commencement perdu. Paris: PUF.

Henry, M. (1990). Phénoménologie matérielle. Paris: PUF.

Henry, M. (2000). Incarnation: Une philosophie de la chair. Paris: Seuil.

Henry, M. (2001). Eux en moi: Une phénoménologie. In A. Amorim et al. Os outros e meu (pp.135-142). Porto: Ipatimup.

Henry, M. (2004). Débat autor de l'oeuvre de Michel Henry. In M. Henry. Phénoménologie de la vie (Tome IV). Paris: PUF.

Henry, M. (2010). Les sciences et l'ethique. Covilhã: LusoSofia. Récupérée le 3 Mars, 2016, de http:// www.lusosofia.net/textos/henry_michel_as_ciencias_ e_a_etica.pdf

Marion, J-L. (2003). Le phénomène érotique. Paris: Grasset.

Marques, M. S. (2002). A medicina enquanto ciência do indivíduo. Lisboa: Faculdade de Medicina da Universidade de Lisboa.

Received: February 22, 2016

Final version: March 3, 2016

Approved: March 17, 2016 